811.163.41'373.611 821.163.41.08 Костић Л. https://doi.org/10.18485/sj.2020.25.1.26

ЂОРЂЕ М. ЈАНКОВИТ *

Универзитет у Београду

Учитељски факултет
Оригинални научни рад

Примљен: 15. 10. 2019.

Прихваћен: 15. 01. 2020.

\title{
ЗНАЧЕЊА НЕОЛОГИЗАМА ЛАЗЕ КОСТИЋА ГРАЪЕНИХ НУЛТИМ СУФИКСОМ
}

У раду се анализирају творбена значења неолошких твореница у делима Лазе Костића грађених нултим суфиксом. Износи се класификација тих значења и испитују семантичке везе међу њима. Утврђује се да је највећи број лексема код Костића употребљен са резултативним значењем и износи претпоставка да оно настаје механизмима полисемије према основном, глаголском значењу. Као главни семантички фактори који дају плодност овом творбеном моделу издвајају се флуидност међу значењским класама, потенцијална експресивност деривата и партикуларизација значења.

Кључне речи: творба нултим суфиксом, nomen actionis, nomen acti, nomen resultativum, деривација значења, механизми полисемије.

\section{1. ПРЕДМЕТ РАДА И ГРАЂА}

1.1. Рад се бави анализом значења именичких твореница грађених нултим суфиксом у делима Лазе Костића. Обухваћене су девербативне лексеме мушког и женског ${ }^{1}$ рода, настале првенствено суфиксацијом, али и сложеносуфиксалном и префиксално-суфиксалном творбом. Њихова значења се кла-

\section{*djordje.jnkvc@gmail.com}

${ }^{1} \mathrm{C}$ обзиром на слабију фреквентност, именице женског рода ће бити посебно обележене, док ће се именице мушког рода третирати као необележене. 
сификују према блискости везе с глаголском радњом и на основу тога одређују семантички хијерархијски односи (семантичко извођење).

Костићев језик је одабран због његове стилске прегнантности и значењске разноврсности, а неологизми с нултим суфиксом наметнули су се као плодан творбени модел, специфичан и са формалне и са семантичке стране.

1.2. У корпус је ушла већина Костићевих песама и поема, све три његове драме и филозофски трактат Основно начело. Костићево дело из теорије естетике Основа лепоте у свету..., монографија О Јовану Јовановићу Змају..., као ни незнатни део његових песама нису прегледани. Неологизми из тих дела дефинисани и цитирани у Речнику САНУ ушли су, ипак, заједно са осталим јединицама, у регистар, који дајем ниже, у анализи.

За упоређивање и евентуалну допуну грађе користио сам материјал који су сакупили Марковићева (1986) и Јанковић (1969), у који улазе све Костићеве кованице. Марковићева је, осим онога што се налази у мојој грађи, прегледала још и Костићева писма, јавна и приватна, и запазила да она не садрже кованице (1986: 285, 290). Нисам укључивао неологизме из Костићевих превода, обрађене у Јанковићевом речнику. ${ }^{2}$

\section{2. СЕМАНТИКА ДЕРИВАТА С НУЛТИМ СУФИКСОМ}

2.1. Именице с нултим суфиксом носе различита значења. У литератури се оне, мање-више без разлика (Грицкат 1981; Бабић 1981, 1986; Клајн 2003), сврставају у неколико семантичких група: nomina actionis, nomina acti, nomina resultativa, nomina loci, ,peђе nomina instrumenti, a Hajpeђe nomina agentis” (Грицкат 1981: 106)․․ Када се види ова шароликост - која је и разумљива, с обзиром на то да су глаголи речи најбогатије граматичко-семантичким валенцама ${ }^{4}$ - онда постаје блиска тврдња да „у овој области хијерархија значења

${ }^{2} \mathrm{C}$ друге стране, у РСАНУ није нађена ниједна кованица из Костићевог Основног начела, као ни поједине друге одреднице, попут над, недоскок (док су ненажар, неповред, непровир обрађени!), па би моји примери из регистра могли послужити за допуну корпуса тог речника. То важи, рецимо, и за именицу слад, која је у РМС забележена искључиво у мушком роду, док је код Костића она фемининум.

${ }^{3}$ Бабић (1981: 35) том списку додаје именице које означавају особу (пребег, пророк), збир (народ, скуn), те зоониме (удав, поскок), фитониме (ослад, подбјел), па чак и топониме (Осијек, Прокоп), чиме класификацију, уводећи више критеријума, чини некохерентном, будући да је нпр. народ nomen resultativum, а да су пребег, пророк, удав, поскок, ослад, подбјел скупа nomina agentis, од којих последње четири спадају у нарочите семантичке подгрупе.

${ }^{4}$ Стога би глаголски деривати nomina actionis/acti одражавали транспоновано са́мо значење глагола, nomina agentis - значење њиховог субјекта, nomina resultativa - објекта глагола, nomina loci - значење месне одредбе глагола, а ниже ћу показати да има примера и за речи настале метонимијским везивањем значења глагола за његову одредбу времена. 
и блискост семантичких прелива не само што су променљиве и танане, него често и у правом смислу неухватљиве” (1998: 36).

Уместо простог пописивања значења, које је за ове речи углавном одавно урађено, овде ћу акценат ставити управо на њихову хијерархијску уланчаност и „блискост”. Из тога се разуме да појаву третирам из перспективе деривационе семантике и њених деривационих механизама, која је, према Падучевој (2003: 230), у тесној вези с динамичком и композиционом семантиком, заснованом на поставци да лексеме значења добијају искључиво у контексту, чиме се стриктно везују за наше ванјезичко знање, и да се, следствено, сва њихова неосновна значења могу повезати с оним базичнијим уз помоћ правила̂ семантичке деривације, што на крају ствара полисемантичку структуру. Падучева као главне механизме у семантичкој деривацији наводи промену категорије значења - метафору, промену фокуса у појму - метонимију, те семантичко „блеђење” (што одговара деплецији, како је описана у Драгићевић 2007) и контекстуално обогаћивање значења (у шта би се, између осталог, могла сврстати аутотропонимија $\left.{ }^{5}\right)$.

(Такво виђење семантичке деривације карактеристично је за западну лингвистику, али и за руске лингвисте млађе генерације. Старији лингвисти, попут Виноградова, семантичку деривацију посматрали су као дијахронијски процес [према Зализњак 2001], а њене резултате као хомониме, добијене распадом полисемантичке структуре, што у србистици заступа Р. Маројевић [2005].)

У овом раду се стога узима да нпр. значења лексема̂ ручиц̧а 'мала рука' и ручица 'дршка' стоје у директној семантичкој вези (било метафорској било метонимијској), те да представљају алолексе. То значи да и сва значења девербативних именица на нулти суфикс третирам као сродна и као реализације једне лексеме, на трагу коментара Ирене Грицкат, писаног, додуше, из дијахронијске перспективе: „Из значења правих nomina actionis издвајале су се неке блиске семантичке поткласе и друкчије семантичке класе [...]. Нека семантичка померања би се могла тумачити као својеврсне метонимије. Nomina agentis могу бити врста синегдохе. Често исте именице живе у разним класама, о чему нас обавештавају сви већи речници” (Грицкат 1981: 106).

${ }^{5}$ Наглашавам да се у поменутој теорији контекст разуме као основни чинилац значења и значењских промена, те би се у том смислу свака аутотропонимија имала тумачити као засебно значење, за разлику од погледа изнесеног у Драгићевић 2006 (229), по ком пити у значењу 'пити много' јесте аутотропоним, али коштати 'коштати много' није, јер, како се наводи, у потоњим примерима саговорник „претпоставља висок степен својства”. Управо та „претпоставка", као основ принципа комуникације, иначе омогућава разумевање контекста и значења речи, што важи и у свим другим облицима полисемије (Појео сам тањир супе : Разбио сам тағир), па и међу хомонимима (Наоштрио сам косу : Очешььоо сам косу), те није differentia specifica за раздвајање различитих значења од реализација једног значења. 
2.2. Наведеним принципима семантичке деривације могу се објаснити општи случајеви развијања значења лексема. У творби речи ти су принципи понешто другачији, о чему пише Т. Прћић (2016: 91-103). Према овом аутору, у развоју значења деривата уочавају се две појаве: композитивност и идиоматизација. Ова прва подразумева „наслеђивање” сема творбених форманата од којих је лексема саграђена (оне се називају интерна обележја и предвидљиве су), док се употребом лексеме у контексту њен сематски састав мења, постаје индивидуалан, непредвидљив, било у виду губљења интерних обележја (декрементација), било у виду добијања нових, екстерних обележја (инкрементација), а врло често комбиновањем обеју могућности.

То, на примеру именица које се овде разматрају, значи да би се семантичке класе девербатива на - $\varnothing$ могле објашњавати уз помоћ додавања и одузимања семантичких обележја. Ако би се као основни узео nomen actionis, типа налет 'налетање', онда би nomen acti имао диференцијална обележја [- трајање] [+ чин] (декрементација и инкрементација), вез 'извезена шара' би према вез 'везење' имао обележја [- трајање] [+ резултат] итд. ${ }^{6}$ Ипак, у томе би требало бити опрезан, јер, према И. Грицкат (1981: 106), „[н]ије искључено да су се неке, па и многе од [именица типа налет], непосредно увршћивале у једну од 'метонимијских' или других класа, не пролазећи кроз фазу nomina actionis". Ова је ограда, с друге стране, дијахронијског карактера и она, као ни чињеница да је доминантно значење нпр. лексеме вез, према РСАНУ, резултативно а не глаголско, не суспреже могућност да се анализи значења приступи са становишта творбеног осећаја говорника̂ и као примарно у процесу семантичке деривације узме чисто глаголско значење (што, наравно, не би могло важити за слабије мотивисано шав $\leftarrow$ шити или сасвим немотивисано резултативно кров, исток, образ...).

Треба још скренути пажњу на то да у процесу семантичке деривације (девербативних) твореница битну улогу игра прозодија. Познате су опозиције

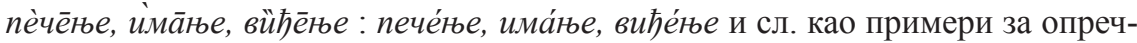
ност између радње и њеног резултата/чина. У савременом говору, међутим, и прозодијске творенице поштова́ъе, ангажова́ъе, путова́ъе, именова́ъе (које би с тим акцентом првенствено означавале осећање, односно чин) редовно преузимају и значења nominum actionis лексема од којих су настале (нпр. Берлин је за ангажова́ње НАТО-а на граници са Сиријом; Заузимају се за поштова́ғе примирја - примери из медија). Као редак пример за акценатско разграничавање глаголског од изведеног значења девербатива на нулти суфикс забележио сам однос глӓвосе̄к 'одсецање главе' : главо̀сек 'онај који одсеца

${ }^{6}$ За ове примере се ипак не може извесно утврдити да представљају идиоматизацију деривата, будући да они наведене семе добијају и губе регуларно, механизмом метонимије, па тој појави недостаје обележје непредвидљивости, какво постоји у примерима попут дописник (агенције) : *мој дописник. 
главу' (РСАНУ), мада обе те акценатске могућности иначе функционишу у релативно слободној дистрибуцији (рйкопйс, камено̀лом) или као дублети (дӧпринос/допри́нос). С обзиром на бројност двосложних именица типа налет и на њихову значењску раслојеност, зачуђује што постојање чак три могућности за њихово акцентовање, данас спроведене углавном слободно (nри́ход, ѝзбор, ӥзглед), није искоришћено за диференцијацију значења.

2.3. У литератури не влада једнак став према односу именица на - $\varnothing$ и вида њиховог мотивног глагола, односно према њиховом афинитету да изражавају трајање радње (actio) или само њен чин (actum). Бабић (1981: 35), Грицкатова (1981: 109-110) и Клајн (2003: 215) слажу се, с једне стране, да префигирани девербативи не зависе од вида мотивног глагола (тј. да налет може означавати и 'налетање' и име чина), али различито гледају на значење деривата простих глагола (нпр. лет). Клајн констатује да за њих „није карактеристично” значење радње с неодређеним трајањем, а Бабић их доводи у везу с видом мотивног глагола, мада и у томе набраја мноштво изузетака, а класификацију неоправдано усложњава трећим типом - групом именица које су према виду глагола неутралне. Најтачнијим и методолошки најпрецизнијим чини се решење Ирене Грицкат (1981: 108), која сматра да се код свих девербатива на - $\varnothing$ радња приказује ,растерећена нагласка на видском моменту или уопште ослобођена видског

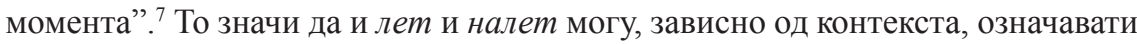
и радњу која траје и глаголски чин, с тим што је код тих именица, за разлику од лексема летење и налетање, „мање истакнуто дуративно значење” (109)8. Схематски би та репартиција значења, условљена семантичким окружењем а не мотивном речју, изгледала овако:

(1) Зачуо се његов пад. ТРЕНУТНА РАДЬА, СВРШЕНИ ЧИН

(2) Слободан пад је трајао неколико минута. ТРАЈНА РАДЬА

Ипак, ауторка уочава да, осим свршеног чина, ове именице могу означавати и комплексно виђену радњу, те за примере попут Њутна је инспирисао пад јабуке уводи посебну категорију, (3) комплексни чин/комплексни догађај, која би се као поткласа могла сврстати уз именице које означавају свршени чин (и Грицкатова признаје да их је тешко одвојити).

Мада остаје непознато је ли ауторка напомену дату уз однос именица сејање и сетва, да прва означава радњу in abstracto, а друга радњу in concreto (110), формулисала као разраду разлике између радње и комплексног чина

${ }^{7}$ И. Грицкат ту особину твореница, коју у раду више пута апострофира, назива њиховом видском испражьеношћу и видском амбивалениијом.

${ }^{8}$ Неубедљивије делују оцене И. Грицкат да и именице типа запослење могу бити видски амбивалентне (1981: 109); примери попут Колико је трајало твоје запослење? ипак се чине мање граматичним. Резерву изазивају и ауторкини примери Додир траје, Слом траје, те би за такве случајеве требало испитати осећање већег броја говорника. 
каква је приказана горе, изгледа да се та два случаја свеједно могу довести у везу. Ако се на страну стави предложена дистинкција апстрактно-конкретно, која вероватно није довољно прецизна јер асоцира (и) на разлику између генеричког и референцијалног, о којој овде није реч, рекло би се да између сејањ $a$ као било које врсте те радње и сетве као специјализованог сејања одређених култура, које се одвија у одређено време, на одређени начин - дакле, у одређеном семантичком сценарију; односно да између било којег пада и пада (јабуке) као физичке појаве - важи исти однос.

\section{3. ЗНАЧЕЊА КОСТИЋЕВИХ НЕОЛОГИЗАМА НА НУЛТИ СУФИКС}

3.1. Ексцерпиране неологизме сам поделио у три велике групе лексема. У прву се могу сврстати творенице с основним, глаголским значењем (најчешће трајним) - nomina actionis.

1. брид (СМДС9: „ал’ тежој рани настаде брид”)

2. гуд (НПВК: „прамалетње нам песме хранећ гуд”)

3. гук (МЗ: „у стоструком зборе гуку”, „не чујем [...] мамна гука”)

4. дисак (МД: „већ ми дисак загушују | јучерањим задасима | животова разилаза")

5. горук (СиД: „у горуку жртвеног светила”, „Чује се горук светог пламена")

6. залаз (ПП: „[пада жар] сунашца на залазу”)

7. звек (ЕРС: „трепетљике звеком звече”, СиД: „надјекује окова тужни звек")

8. кај (Паризу: „Ал’ нема раја! Заман га вабе | последњим кајом синови доба")

9. кар (Сид: „те намигнув измичаром, | постиђеним женским каром, | ти завитла, ја прихватих")

\footnotetext{
${ }^{9}$ Уместо засебног регистра, који би био прегледнији, али тежи за непосредно коришћење, ексцерпиране одреднице с примером/примерима употребе наводим овде. Називе дела из којих сам црпао грађу наводим (углавном скраћено) на следећи начин: ЂС = Ђурђеви ступови; Дим = Дим; ДсЖ = Дужде сежени; ДК = Дон Кихоту; ЕРС = Еј, ропски свете; ЈП = Јадрански Прометеј; МЗ = Међу звездама; $\mathrm{MД}=$ Моја дангуба; МЦ = Максим Црнојевић; НПВК = На парастосу Вука Ст. Караџића; НПЈБ = На парастосу Јелене Боздине; ОШТ = О Шекспировој тристагодишьици; $\mathrm{OH}=$ Основно начело; ОЖ = Ох, жао ми те је; Паризу = Паризу; П = Прометеј; ПИЈД = Певачка 'имна Јовану Дамаскину; ПП = Постанак песме; ПР = Последњ а ружа; ПС = Пера Сегединаи; Разговор = Разговор; СиД = Самсон и Делила; СЛ = Славуј и лала; СМДС = Santa

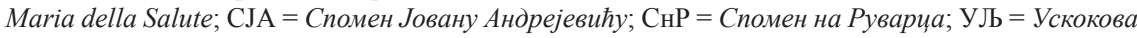
љуба. Римски број уз називе драма означава чин.
} 
10. кип (ОЖ: „И преста плам, и преврела је врева, | и утиша се срцу кип, | ал' ни од куда руке, да долева | у срца мога недосип!"')

11. мил (СиД: „Јер онда би тек Делила | тог остатка вредна била | десна руко, твога мила")

12. часомил (MЦ IV: „Па ко је кривац часомилу том?”)

13. пирук (СнР: „ко̂ поноћнога ветра пирук”)

14. повлад (СиД: „Поклонише се старци у повлад, | у један клим, у један брадоглад")

15. послед (ПС II: „тај не сме поћи сам на онај свет, | један нас мора њему у послед”)

16. потвор (ОШТ: „Вештака вечног творилачка свест [...]| и своју слику створи, човека $[\ldots] \mid$ И по томе не беше потвора")

17. разилаз (МД: „већ ми [успомене изумрлих пријатеља] дисак загушују | јучерањим задасима | животова разилаза")

18. сикут (ОШТ: „[бог се оправља да стопи] славуја глас, сикута гујског бес")

19. снебив (СиД: „Па те чежње, тог снебива [...]! Тог судара изобиља разиграних двеју сила | од омразе, од омиља!”)

20. трај (ПИЈД: „рушећи вечним надама трај”)

21. трес (ЂС: „стреса се слика у тресу све јачем”)

Све се оне могу парафразирати глаголском именицом на -юе: гукање, дискање, залажење, кајање, карање... Морфолошки су атипичне лексеме пирук и сикут, значењски везане с глаголима пиркати и сиктати, а творбено контаминиране с извођењем типа горукати-горук. Дисак може бити и од дисати, са суфиксом -ак. Са семантичке стране, то би могао бити и nomen acti $(y \partial u c(\kappa) a j)$.

3.2. У следећу семантичку класу спадају лексеме које у Костићевим песмама означавају чин радње (nomina acti). То значење је с основним повезано онтолошки, метонимијски.

1. брадоглад (Сид: „Поклонише се старци у повлад, | у један клим, у један брадоглад")

2. бриз (МЗ: „Гласи мука и покаја, | шапат јада, сузни бризи”, СЛ: „вечити плач и бриз")

3. вик (СиД: „Колико беше милостив му вик, | толико страшан говорников лик")

4. врв (Паризу: „све се то клања у живом врву”)

5. врис (СиД: „из куће се зачу врис”)

6. глед (ПС ІІ: „ни примит не хте просна гледа мог”, „од милокрвна прва гледа јој”, СМДС: „,...] у душу свесну | никад још такав не сину глед”, ДсЖ: „У издисају последња гледа”, МЗ: „згледају се чудним 
гледом”, СиД: „И један глед и један живи гред - | на Делилу је пошоิ у полет”, „отопили би се од њена гледа”)

7. гред (Сид: „[образ указа се блед:] аскалонски се млади чини кнез, | и један глед и један живи гред - | на Делилу је пошоิ у полет")

8. дир (ПС ІІ: „шат милу крв поврати, мрски дир”, СиД: „[нема свата] да се такне смелим диром | Самсонова дивског тела")

9. заклет (СиД: „па, божанску погледајући клет, | намигују: 'Сад оде на заклет"')

10. залут (СМДС: „опрости моје грешне залуте”)

11. клим (СиД: „Поклонише се старци у повлад, | у један клим, у један брадоглад")

12. крес (ЈП: „и див се крену, пробуди га крес”) „,Орлушина] у ребра г” удри двокљунимице. | Из кремен-груди не потече крв, | ал' кремен кресну, орла посу плам [...]| и див се крену, пробуди га крес"

13. крет (СиД: „што из крета сваког бије”)

14. љуљ (СиД: „нек искаже на загрљајни љуљ | чиновној снази шта му бива виг”, РСАНУ (часопис Матица за 1867): „Закон шеталичног љуља могао би се у томе готово математично применити на покрете човечије душе")

15. надах (ОН 81: „надах маште”)

16. надим (СиД: „[осмејак] што с’ из отих дивских груди | у надиму тешком буди")

17. недоскок (ОН 9: „после недоскока се не враћају, него поново довуку се до опкопа")

18. одбој (ОН 21: „У ње [симетрије] влада исто начело што у динамици удешава притег и одбој, атракцију и репулсију, центрипеталну и центрифугалну снагу, што одређује размере у клаћењу клатна”, $\mathrm{OH}$ 74: „свака навала [...] свршавала би се обично неким одбојем, да не речемо неком омразом")

19. опорав (ЈП: „рад опорава, ох, рад освете”)

20. показ (СиД: „Један цик тек, један скок тек, [...] | и ево га до невесте | без показа вида свога, | без очију дана бела [тј. слеп]")

21. поруг (МЦ II: „на сваки поруг - један пољубац”)

22. презор (ПС II: „Голобрад момак [...] | да Перу држи ни пода шта зар? Тај презор му не прође олако")

23. прекип (ОЖ: „скино бих с груди гвоздена мандала [...]| и опет врева, опет жари знани, | и опет прекип, опет угас, јаo!”)

24. преплет (ОН 73: „преплет разума и маште”, ОН 78: „малаксавање у растрој свих уплета и преплета [...] свег израза тог укрштаја")

25. притег (ОН 21: „У ње [симетрије] влада исто начело што у динамици удешава притег и одбој, атракцију и репулсију, центрипеталну и центрифугалну снагу, што одређује размере у клаћењу клатна") 
26. развлак (МЦ I: „Од Максима да л’ [валови] носе поруке | ил’ у развлаку сваком дубоком [доносе нова питања]")

27. увељ (МЗ: „Лепирица као бела | кад би собом цвет понела, | да га виса спасе веља | од земљина од увеља: | тако вила поне мене")

28. угас (ОЖ: „и опет прекип, опет угас, јао!”)

29. уплет (ОН 78: „малаксавање у растрој свих уплета и преплета [...] свег израза тог укрштаја")

Њих карактерише особина свршености глаголске радње или радње појмљене као појединачни чин. У том, аспектуалном смислу нултом суфиксу су конкурентни суфикси - $a \kappa,-a j$, - ћe, - $a$, -ва (врис би значило приближно исто што и врисак, тако и опорав-опоравак, загрл-загрљај, крес-креснуће, врв-врева, заклет-заклетва). Према тематском критеријуму, без засебних семантичких одлика, могу се издвојити именице које означавају покрет: брадоглад, гред (ако није чист резултативум 'корак'), дир, клим, крет, љуљ, преплет, развлак, мада би све оне, чини се, могле имати и резултативно значење. Одређени број девербала из ове групе носи и значење специфичне радње (радње in concreto), горе разматране на примеру И. Грицкат сејање-сетва: то су (шеталични) љуљь, притег и одбој (Костићеви преводи за осиилащију, атракиију и репулсију), који су, узгред, за разлику од неутралних љуљање, притезање, одбијање, због тог значења и бољи кандидати за терминолошке називе радњи или њихових чинова. Необична је формација недоскок, чија се неповезаност с резултативним значењем простог скок види по томе што се може парафразирати као клауза: после недоскока 'након што не доскоче'.

3.3. Трећу, најхетерогенију групу именица чине оне које означавају разне врсте метонимијских, конкретнијих или апстрактнијих опредмећења ${ }^{10}$ глаголских радњи у категоријама места, времена, бића - особе, појаве, звука, осећања и др., заснованих на фокализовању одређене семе глаголског значења или граматичке категорије. У њих спадају и nomina resultativa. Творбено се могу парафразирати уз помоћ општих/упућивачких речи с одговарајућом категоријалном вредношћу и глаголског дела дефиниције: 'онај који врши радњу именовану глаголом', 'оно што...', 'место где...', 'време кад...' и сл.

1. глум (НПЈБ: „,[позориште] у ком се глуми само један глум, | ал’ према том су други глумови | коิ према сунцу ситне звездице”, „у позоришту глума сунчаног" и др.)

2. гроз (МЦ ІІІ: „Божаствен личе, не чујем ти глас $\mid$... $\mid$ ал’ осећам ти стапајући гроз”; гроз/грӧза ПС II: „да прича [гроิзе]/[грӧзе] мука вечитих”, СиД: „Делила се [гроิзом]/[грӧзо̄м] стресе”)

${ }^{10}$ Уп. и термин реификација (постварење) за ову појаву (Хлебец 2006). 
3. докон (ОН 37: „ту је вршак начела укрштаја, ту је његов докон, крајна мета Дарвиновог intercrossing-a”)

4. домах (OH 55: „Аристотел је дакле баш управо својом жестоком навалом на основно начело Емпедоклово и Хераклитово у одмаху и домаху свога духа")

5. жас (ОШТ...: „утишај часком наваде ти жас”)

6. жест м/ж (МЦ IV: „причујмо му жес"”)

7. жест ж (СиД: „[Ђаво] улови ми гујном замком | обезумну моју жест")

8. жуд м (СМДС: „[нуди ми] сву своју душу, све своје жуде”)

9. жуд ж (МЦ ІІІ: „напитљиву намирити му жуд”)

10. загрл (СиД: „у жестоком, у загрлу | грудима те дигох врлу”)

11. замисао м (ПС ІІІ: „Грех тешки кају лаком кичицом, | замисао лак у тешки режу кам")

12. зимогроз ж (МЦ ІІ: „И тај му беше поносити стас | и погледа му чудна зимогроз, | што њему доби потурицу ту”, МЦ ІІІ: „Бадава преклињеш, | облажући топлотом речитом | чудноватости своје зимогроз”, П: „у колених му чисто зимогроз")

13. зјап (СиД: „[Зар је то] тих вилица грдни зјап?”)

14. јез (ОШТ: „сред летњег жара зимогрозан јез”)

15. кив (ПС II: „Ал’ ипак ми на тебе није кив”, СиД: „на њој, на њој, кив искал'те")

16. клат (ОН 29: „објашњавајући Хајгенсов опит са два клатна, која би се свакад сама удесила у једнаки клат чим би се једно хотимице зауставило")

17. колотер (МЦ II: „То мукло време, тако споро сад, | брзоплетан иначе напредњак, | колотер тај на кол'ма судбине")

18. косотрес (СиД: „И не сакри осећаја, већ из грудног испотаја, | из увојна косотреса, | из осмејка боног теза, | у један се уздах слива: | 'Ох Делила!'”)

19. крас (ОШТ: „И опет не: та дела твојих крас |пренашоि је и сваког тамо [у рају] нас”, СиД: „Увојке му глади власа | са чеоног што се краса $\mid$ до јуначког вију паса")

20. кукурик (СнР: „до прва кукурика”, „издајство Петра, петлов кукурик")

21. лег (СЈА: „та беше нам липа | славујма српским у срцу лег”)

22. лог (ОШТ: „[Бог] На особит оправљао се рад: | у једном лику, једном животу, | створења сву да смести дивоту, [...] | у један лик да сложи, један лог, | и учини, - Шекспира створи бог")

23. љуб (ПС II: „Примајући зраковни му љуб”) 
24. мор (ОШТ: „Зар тако тежак човек беше мор | да бог за њиме треба одмора?")

25. м мраз (ПС III: „успемо ли, сва слава иде вас; | буде л' натрашке, на ме пада мраз")

26. над (МЦ I: „и освете већ над мис'о крза”, „жив је опет над”, МЦ III: „испис'о бих му живим жељама [...] | из другог света боље среће над”, ПС I: „полаже над”, ПС III: „живота над на њему разапет”, CJА: „[Је л’ чудо што...] гонимо над”, ЂС: ,jер над је тај греје од главе до стопе", „од главе до стопе дркћући од нада”, ОШТ: „та над је све што народ има млад”, „у наду том и твоја нам је сен”)

27. намен ж (ЈП: ,[кликће, стиска] та као да слути мајчину намен”)

28. наслад ж (ДК: „кад јунаке видим старе | где их скотска наслад гњили | те сад оно пале, жаре, | чем су били борци чили ")

29. недозив (СиД: „а ја вам одох сад у недозив”)

30. недосип (ОЖ: „И преста плам, и преврела је врева, | и утиша се срцу кип, | ал' ни од куда руке, да долева | у срца мога недосип!")

31. недочек (ПС III: „[отераће нас] отежући свечану проповед [...] | у недоглед, у пусти недочек”)

32. недромир (СиД: „да ми буде недромир [Самсонова коса]”)

33. неисказ (М3: „већ пођите до јавора [...] | побратима оног бора, што га стужи и сасуши | неисказом вељих мука | Косовкина бела рука")

34. ненажар (СиД: „Па на мени шта још оста [осим косе и очију] | да накнаде буде доста | за те страсти ненажар")

35. неодвај (СиД: „Из љубавног неодваја | Делилина загрљаја | Самсон скочи")

36. неостриз (СиД: „[љубав ми нема мере...] ни у бујном неостризу | дивне косе $[\ldots] ")$

37. неповред (ПП: ,јер то [зрак који је запалио срце] је онај неповред | што песмом зове свет")

38. непровир (СиД: „Ох, кам да је за однетак | ове косе силни сплетак, | жеља мојих непровир")

39. непрозрак (МД: „муњско умље како сину, | те обасја приоковље. | Још су само вид'ли боље | вековити непрозрак")

40. несавлад (СиД: „каква ли си, пуста, била, | кад погубих теби војна, | од газански што је врата | одбијао несавлада")

41. овапут (СиД: „Коิ Мојсије на Синају | кад угледа у осјају | снова својих овапут")

42. одмах (ОН 55: „Аристотел је дакле баш управо својом жестоком навалом на основно начело у одмаху и домаху свога духа")

43. омраз (СиД: ,јача љубав нег' омраз”)

44. осам (ПР: „ил' ти је осам веће дотуж’о”) 
45. победопој (ПИЈД: „богу што звеком скрханих негва | припевне гусли [Гпл.] победопој”)

46. подвоз (ОН 82: „ваздушни шар свог умовања снабдео [je] с одушком [...] којом ће свој ваздушни подвоз подићи на више")

47. подоб (МД: „Ама нису јавилици | од подоба древна доба”)

48. покај (МЗ: „гласи мука и покаја”)

49. прикус (ОН 49: „уколико се реч filetes додатком омразе, неслоге, прелива у пријатељство, те тим добија неки призрак и прикус друштвени")

50. притег (ОН 21: „У ње [симетрије] влада исто начело што у динамици удешава притег и одбој, атракцију и репулсију, центрипеталну и центрифугалну снагу, што одређује размере у клаћењу клатна")

51. просијев (Уљ 210: „између просијева и утрнка твоје зенице”)

52. разагрев (СиД: „Но поруга мога дива | потпала ти беше севу, | те у гњевном разагреву | већ се лати мача сива")

53. разбор (СиД: ,[још жешће] просевкују кроз разбор им и суд | Самсонова јуначка чудила")

54. разлег (МЗ: „У то неки звук забруја. | Је л’ олуја? [...] ил’ је разлег од песама")

55. растрој (ОН 78: „малаксавање у растрој свих уплета и преплета [...] свег израза тог укрштаја”, „у слојевима органског растроја”)

56. свит (СМДС: „ко̂ песма славља̂ у зорин свит”)

57. слад м (СМДС: „[нуди ми] јаде па сладе, чемер па мед”,

58. слад ж (ОЖ: „и прекипе живота прва слад”)

59. стрв (П: „на најбоље јунаке му је стрв”)

60. стриз (СиД: „стриз по стризак, низ по низак”)

61. тез (СиД: „И не сакри осећаја, већ из грудног испотаја, | из увојна косотреса, | из осмејка боног теза, | у један се уздах слива: | 'Ох Делила!'”)

62. угод ж (СМДС: ,за чим сам чезно, чему се надо, | све је то давно пепо и пра', | на угод живу пакости жуте”)

63. цикут (ЕРС: „цикут и вапај мученички”)

64. шкрип (СиД: „Зар се тако уста љубе | што им зуби роду твоме | на разбоју самртноме | самим шкрипом главе рубе [= одрубљују]")

65. шкрипет (Дим: „Шкрипну врата на дворани | шумом, шкрипетом”)

Међу њима најпре издвајам лексеме које би се могле одредити као nomina agentis и nomina patientis, у које, уз именице што означавају бића (и што се парафразирају са 'онај који'), сврставам и неаниматне именице (парафразиране са 'оно што'). Аниматне агентивне творенице су, према томе, колотер, подоб (од архаичног подобати 'наликовати'), а неаниматне слад, просијев, овапут, мор, недромир ('оно што мирише у недрима'). Пет потоњих именица може се, 
на основу контекста, разликовати и према виду глагола који лежи у њиховој дубинској структури; тако се слад, мор и недромир парафразирају трајним глаголом, а просијев и овапут свршеним ('оно што просевне', 'оно што се оваплоти(ло)'). Од примера за девербале који се парафразирају пасивним глаголским обликом један је аниматни: несавлад 'онај који се не може савладати', док остали означавају неживо: глум 'оно што се глуми', намен 'оно што је намењено', замисао (м.!) 'оно што је замишљено, што се замисли', победопој 'оно што се поје после победе $\rightarrow$ песма победе', а у њих спадају и негиране творенице са додатном семом могућности недочек 'оно што се не може дочекати', неисказ, ненажар, непрозрак, неповред. У лексеме с пацијентивним значењем сврставам и оне које се парафразирају с неправим објектом: жуд 'оно за чим се жуди', непровир 'оно кроз шта се не може провирити', недосип 'оно у шта се не може до краја досути').

Даље се међу творенице конкретнијег (или одређенијег) значења од општег глаголског могу издвојити оне које означавају време (свит 'време/ тренутак кад свиће') и место (лег 'место где се лежи', лог 'место на које се нешто ложи = полаже', крас 'место које се краси'11, недозив 'место одакле се (ко) не може дозвати', косотрес 'место где се тресе коса', докон 'место где се шта дочне/дочиње = доврши/довршава').

У следећој подгрупи твореница реификованог значења биле би оне које се односе на радње што се могу опазити чулима, најпре слуха: имена звукова шкрип, шкрипет, кукурик, иикут, разлег, али и чулима вида/додира: имена покрета и гестова љубб, стриз, гред, тез. На чуло укуса се односи именица прикус, општијег значења од наведених и семантички сродна лексеми укус.

Њима блиске, али везане за радње које се тичу човековог психолошког доживљаја јесу бројне творенице које означавају осећања и психолошка стања: гроз, жас, жест, жуд, зимогроз, јез (према јежити се, с депалатализацијом), неодвај, кив, мор, мраิз, над, наслад, омраз, осам, покај, разагрев, растрој, стрв, угод. Наведени примери кив и угод, као и крас, које означава само особину, блиски су придевској парафрази 'стање када је ко киван, када је коме угодно', али се могу изводити и из глаголаิ. Специфична је семантика лексеме стрв, која не одговара сасвим глаголу стрвити 'чинити да ко постане стрв(ина)' и која би се пре, мада то формални творбени критеријуми не дозвољавају, могла повезати са острвити се (стрв 'стање када се ко острви'). Значење општих а не психолошких стања имају творенице зјап и неостриз 'стање када ко није острижен'.

Најзад, аналогно у претходној тачки разматраним дериватима са значењем специфичне појаве (у Костићевом случају филозофског принципа), и речи с

\footnotetext{
${ }^{11}$ Вероватније је ипак придевско тумачење 'красно место'.
} 
резултативним значењем познају такве случајеве: клат, домах, одмах. (Оне би се могле подвести и под тематску групу лексема са значењем покрета.)

4. Изложивши семантичку анализу материјала, обратићу пажњу на неколико значењских специфичности. Истраживане творенице могу развијати полисемантичку структуру, за разлику од тврдњи које у вези с таквим или сличним твореницама налазе у литератури (уп. Марковић 1993: 288; Д. Ратковић 2009, према Милановић 2012: 671). Тако је значење лексеме, рецимо, зимогроз у примерима зимогроз чудног погледа, зимогроз чудноватости настало на појмовној метафори (НЕПозНАТо (НЕОБично) ЈЕ ХЛАДНО), док У примеру зимогроз у коленима она има основно значење. Слад у значењу 'пријатност' настало је такође метафором (ПријАтно ЈЕ слАтко). Некад се сликовите творенице користе као изворни домен за разумевање апстрактних појмова (нпр. у ПерсонифиКацији ВРЕМЕ JЕ КОЛОТЕР НА КОЛИМА СУДБИНЕ).

С друге стране, у примерима попут гред, коме РСАНУ придаје значење 'ход', видимо ново, метонимијско (синегдошко) значење, 'корак' (РАдњА зА РЕзУЛтАТ РАДњЕ). И у реченици Причујмо му жест девербатив има не значење стања/особине, већ њиховог продукта. Творенице трај 'трајање' и увељ 'увену́ће' не означавају само наведене радње него имају и шире значење: 'постојање' односно 'смрт'. Једну, специфичну компоненту значења наглашавају и творенице слад 'пријатност' и оглед 'двобој'. Слично томе, твореница неодвај, с приближним значењем 'стање присности', истиче, као и претходне две, сему физичког доживљаја радње и стога је експресивнија и стилогенија (уп. Јанковић 2019: 466-467).

Уопште, девербативне творенице Костићеве у први план стављају конкретну, опипљиву ситуацију (уп. гас са општијом и апстрактнијом лексемом гамење). У случају имена за чин радње и њеног резултата та се ситуација може појмити као оделита (сев, сикут, показ итд.) и квантификовати (стриз по стризак; на сваки поруг - један пољубаи; у један клим, у један брадоглад).

5. На крају, може се оценити да истраживани деривати углавном носе у литератури описана значења, али да она, иако разнородна, нису неповезана и засебна, већ да формирају (поли)семантички систем, који се у ређим случајевима може очитовати и на појединачним примерима. Као основна значења ових твореница издвајају се значења глаголске радње, из којих се метонимијски изводе значења чина те радње, као и конкретн(иј)а значења, с различитим архисемама, на основу којих се оне могу груписати (агентивна, пацијентивна, временска, месна, значења радњи које се опажају и доживљавају...). Бројност пак примера са секундарним, резултативним значењем показује да је оно за ову групу деривата, макар у Костићевом стваралаштву, постало доминантно. 


\section{ГРАЂА}

Костић 1961: L. Kostić, Osnovno načelo, Beograd: Kultura.

Костић 1962а: Л. Костић, Песме. Прозни списи (Одабрана дела I), Нови Сад - Београд: Матица српска - Српска књижевна задруга.

Костић 1962б: Л. Костић, Трагедије. О позоришту (Одабрана дела II), Нови Сад - Београд: Матица српска - Српска књижевна задруга.

Костић 1964: Л. Костић, Максим Црнојевић; Пера Сегединац, Београд: Сасвремена администрација.

Костић 1987: Л. Костић, Драме, Београд: Нолит.

Костић 2009: Л. Костић, Песме, Антологија српске књижевности, на сајту: www.ask.rs

\section{ЛИТЕРАТУРА}

Бабић 1981: S. Babić, Tvorba imenica nultim sufiksima, Bilten Zavoda za lingvistiku, 4, 4-52.

Бабић 1986: S. Babić, Tvorba riječi u hrvatskom književnom jeziku, Zagreb: Jugoslavenska akademija znanosti i umjetnosti - Globus.

Грицкат 1981: И. Грицкат, О именицама типа налет у српскохрватском језику, ЗбМСФЛ, XXIV/1, 101-134.

Драгићевић 2006: Р. Драгићевић, Семантички односи слични полисемији, НССУВД, 35/1, 227-234.

Драгићевић 2007: Р. Драгићевић, Лексикологија српског језика, Београд: Завод за уџбенике.

Драгићевић 2008: Р. Драгићевић, Творбени и семантички статус једног значења именица типа ручица, Српски језик, 13/1-2, 203-213.

Зализњак 2001: А. Зализняк, Семантическая деривация в синхронии и диахронии: проект „каталога семантических переходов”, Bопросы языкознания, 2, 13-25. Прегледано 25. 1. 2017. на сајту http://www. philology.ru/linguistics1/zaliznyak_anna-01.htm

Јанковић 2019: Ђ. Јанковић, Неологизми Лазе Костића и њихова творба нултим суфиксом, Српски језик, 24/1, 459-475.

Клајн 2002: И. Клајн, Творба речи у савременом српском језику I. Слагање и префиксаиија, Београд - Нови Сад: Завод за уџбенике и наставна средства - Институт за српски језик САНУ - Матица српска. 
Клајн 2003: И. Клајн, Творба речи у савременом српском језику II. Суфиксација и конверзија, Београд - Нови Сад: Завод за уџбенике и наставна средства - Институт за српски језик САНУ - Матица српска.

Марковић 1993: Д. Марковић, Кованице Лазе Костића и дискурс, НССУВД, 21/1. 285-294.

Падучева 2003: Е. Paducheva, Lexical meaning and semantic derivation: the case of image creation verbs, $y$ : Second International workshop on generative approaches to the lexicon. Geneva: Université de Genève, 230-237.

Прћић 2016: T. Prćić, Semantika i pragmatika reči, Novi Sad: Filozofski fakultet.

Ратковић 2009: Д. Ратковић, Речи са интерфиксима у српском језику, докторска дисертација одбрањена на Филолошком факултету Универзитета у Београду.

PMC: Речник српскохрватскога књижевног језика IV-VI, Нови Сад: Матица српска.

РСАНУ: Речник српскохрватског книжевног и народног језика I-XIX, Београд: Српска академија наука и уметности.

Хлебец 2006: Б. Хлебец, Реификација именице опасност, НССУВД, 35/1, 235-242.

\section{SEMANTICS OF LAZA KOSTIĆ'S NEOLOGISMS DERIVED WITH NULL SUFFIX}

\section{Summary}

The paper analyzes the derivational meanings of the neologisms from the works of Laza Kostić formed with null suffix. The classification of these meanings is determined, as well as their semantic relationships. I find that the majority of the Kostić's lexemes is used with the resultative meaning and hypothesize that it is created by the mechanisms of polysemy according to the basic, verbal meaning. The main semantic factors that make this derivational model productive are fluidity among the semantic classes, the potential expressivity of derivatives and the particularization of the meaning.

Keywords: derivation with null suffix, nomen actionis, nomen acti, nomen resultativum, semantic derivation, mechanisms of polisemy. 